Against the Tide 



\title{
Against the Tide
}

\section{AN INTELLECTUAL HISTORY OF FREE TRADE}

\author{
Douglas A. Irwin
}


Copyright (C) 1996 by Princeton University Press Published by Princeton University Press, 41 William Street,

Princeton, New Jersey 08540

In the United Kingdom: Princeton University Press,

Chichester, West Sussex

All Rights Reserved

Library of Congress Cataloging-in-Publication Data

Irwin, Douglas A., 1962-

Against the tide : an intellectual history of free trade / Douglas A. Irwin.

p. $\mathrm{cm}$.

Includes bibliographical references and index.

$$
\begin{aligned}
& \text { ISBN 0-691-01138-9 (alk. paper) } \\
& \begin{array}{cc}
\text { 1. Free trade. } & \text { I. Title. } \\
\text { HF1713.I78 } & 1996 \\
382^{\prime} .71-\mathrm{dc} 20 & 95-25447 \quad \text { CIP }
\end{array}
\end{aligned}
$$

This book has been composed in Times Roman

Princeton University Press books are printed on acid-free paper and meet the guidelines for permanence and durability of the Committee on Production Guidelines for Book Longevity of the Council on Library Resources

Printed in the United States of America by Princeton Academic Press

$\begin{array}{llllllllll}1 & 3 & 5 & 7 & 9 & 10 & 8 & 6 & 4 & 2\end{array}$ 
For my parents 
